\title{
The Return of the Fall of the Quality of the Teacher of ECE? A Few Thoughts on What Teacher Education Might Bring to the Future
}

New Zealand Journal of Teachers' Work, Volume 11, Issue 2, 170-174, 2014

\author{
ANDREW GIBBONS \\ Auckland University of Technology
}

\section{INTRODUCTION: THE FALL OF ECE?}

Kirsty Johnston's week-long New Zealand Herald feature on early childhood education (ECE) fits within wider debates about education and the role of teachers. Johnston's (2015) reports indicated 'sector-wide concerns about quality' in which children might experience some kind of 'developmental damage' because of caring and teaching practices, learning conditions, and management.

Opposition members of parliament, the union, and teacher educators are very concerned about levels of funding needed in order to get back on track with the strategic plan for fully qualified teaching teams (Ministry of Education, 2002). However the Minister and corporate spokespeople regard quality provision failures to be largely isolated and treated appropriately through existing governance mechanisms. The Early Childhood Council (ECC), in addition, argues that the ways in which Government intervenes in the targeting of funding impacts negatively on quality.

I think that the task is not to increase regulation and surveillance but rather to increase support. In terms of purposefully not creating more surveillance and regulation, I presume that the ECC will be happy. The purpose of the Council is to lobby government for less intervention in order to let the market generate and ensure quality ECE via the consumer (ECC, 2013). However in the current debate, are parents hearing that the market is sorry for failing to provide a satisfactory service?

In terms of support I think there is a need to explore how the very debate tends to proceed. The public have been presented with regular revelations about similar concerns, accusations, and recommendations. The debates do not go away, but they certainly fade from public awareness. During the periods of faded attention there are still many advocates and advocacy groups, and more importantly there are the many teachers and student teachers standing up for the things that they are concerned about, standing up for themselves and standing up for others. So for sure people are doing something-without much support until for a brief period media exposure suggests change is vital. If something is going to change, something quite big needs to change in terms of the way the sector supports itself. It needs a big, mobilised, inclusive campaign. Teacher qualifications are one example in which some new thinking about how to be inclusive and supportive might be generated. 


\section{QUALITY AND QUALIFICATIONS}

The New Zealand Herald articles give a sense of consensus on quality. I would like to focus on consensus about teacher qualifications for quality ECE. This consensus discriminates against knowledge and practice that is gained outside of approved educational settings. However, academically-located teacher education knowledge comes from, and is responsible to, community knowledge. The teachers that put into practice ideas about learning through play, about being responsive and reciprocal as teachers and learners, about the centrality of relationships and wellbeing to the curriculum, did not learn or do these things because they got a qualification-for these ideas significantly predate educational qualifications.

Sector reports to the Ministry talk teacher qualifications as if there is consensus that the iron triangle of quality is indisputable. However that is not the case. There is no consensus on the ways in which teacher education focuses on breadth and depth of content (Katz, 2009; Katz \& Rath, 1992); there is no consensus on the ways in which teachers experience the tensions between practice and theory (Osgood, 2012); there is no consensus on the structuring and experience of higher education for the identity of the teacher (Dall'Alba, 2009) and neither is there consensus on the politics that contributed to the forming of academic, professional, and vocational knowledge about early childhood teaching (Davis, 2010; Plotz, 2001; Smeyers, 2008). There is also no consensus on the capacity of an early education to redress social injustice given broader socio-political and economic agendas for the exploitation of human capital (Stuart, 2013).

My point is not to reject teacher education, but to suggest that teacher education is not what we think it is, and that it can and probably should be weakened rather than strengthened-that we should not be looking to create an excess of evidence on competence but rather for the ways in which teachers exercise their voices (Biesta, 2014). In arguing this I am working with Biesta's (2014) notion of weak education and his vision for teacher education which I thoroughly recommend all teachers and teacher educators across the sectors to read. Following Biesta's thoughts on teaching, learning, and education in general, early childhood development, care, learning and teaching are too complex to assume consensus on, and too complex to assume that any one pathway, and any one approach, will make ECE better. Education and teacher education, Biesta (2014) argues, should be more open to questioning the content, the purpose, and the relationships that construct education. This questioning becomes central to the experience of teacher education as transformative-a questioning that places the teacher in her experiences of teacher education and teaching. I think this means questioning one's very qualification to be a teacher.

\section{MISPLACING AND PLACING THE TEACHER}

The late Judith Duncan contributed many influential ideas and challenges to early childhood teaching and to teacher education through her research, her writing, and her advocacy within many ECE networks and organisations. The work that I regularly return to in my thinking, writing, and teaching practice is her 2004 article on 'Misplacing the teacher'. Duncan's work should highlight to us 
the problem of teachers having to hide their identity in order to report on their concerns to the media. This is a serious misplacement of teachers that underscores not just concerns about management and working conditions but also concerns about the very meaning of being a teacher. Placing the teacher in the debates about quality means a safe space to openly question one's own work and the work of those with whom we work.

I would like to focus on how this is a teacher education problem. The task for teacher education is, again following Biesta, to challenge the very meaning of what it means to be a teacher educator because a part of the problem is the disconnect between tertiary education and community, between the idea of being an early childhood teacher and an early childhood teacher educator. There is an ongoing tension between the two roles that, if reconceptualised, might make a significant difference to the ways in which tertiary education in general and teacher educators specifically can support the sector.

Getting into a different relationship with the community does encounter a problem if the identity of the community, from within the community, is unclear. The universities say, and are actually obliged to say, they are for the community. If the community is not calling up this obligation perhaps it is not just because the community feels unable to do this, but because the community is not aware of its nature and role as a community in being the object of the university's obligation.

Some ways in which teacher education providers might make some headway into caring for the community in ways that are generative of community could start with a sustained, enduring relationship with graduates. In order to do this graduates will need to want to keep in touch and so their experience of teacher education will need to be oriented to the idea that this relationship around the study of knowledge and practice is for life. Evidence of that commitment from the university could include lifetime access to research, a culture of 'drop in to talk to us anytime you want, or call us and we will come to your centre'. These are things a university can and should offer because it is already obligated to the community to provide such support for the community. This is a challenge to the current regime of higher education in which where knowledge that the community has already paid is then sold back to them in professional development programmes, or else hides behind publishing paywalls.

\section{CONCLUSION}

This response to the media attention towards the quality of early childhood calls on us to re-think teacher education and teaching qualifications in ways that support the sector, and in particular that support the teacher in connecting to and with her or his community. A starting point will be a new relationship to graduate teachers that makes good on the commitment of higher education to the community through the sustained and enduring sharing of knowledge. While the hurdles of sharing knowledge that are related to the knowledge economy are big hurdles, these are only small steps towards a kind of sector where all early childhood services feel very comfortable with the presence and role of the academy and of teacher education and in the possibility that there are multiple pathways to knowing what it means to be a good teacher and a good teacher educator. 


\section{REFERENCES}

Biesta, G.J.J. (2014). The beautiful risk of education. London, England: Paradigm.

Dall'Alba, G. (2009). Learning professional ways of being: Ambiguities of becoming. Educational Philosophy and Theory, 41(1), 34-45.

Davis, R.A. (2010). Government intervention in child rearing: Governing infancy. Educational Theory, 60(3), 285-298.

Duncan, J. (2004). Misplacing the teacher? New Zealand early childhood teachers and early childhood education policy reforms, 1984-96. Contemporary Issues in Early Childhood, 5(2), 160-177. Retrieved from http://dx.doi.org/10.2304/ciec.2004.5.2.4.

Early Childhood Council. (2013). ECC philosophy. Retrieved from https://www.ecc.org.nz/Section?Action=View\&Section_id=106.

Johnston, K. (2015, April 20). Early childcare services red-flagged. The New Zealand Herald. Retrieved from http://www.nzherald.co.nz/nz/news/article.cfm?c id=1\&objectid=1143523 5 .

Katz, L. (2009). The challenges and dilemmas of educating early childhood teachers. In A. Gibbons \& C. Gibbs (Eds.), Conversations on early childhood teacher education: Voices from the working forum for teacher educators (pp. 8-22). Redmond, WA: World Forum Foundation and New Zealand Tertiary College.

Katz, L., \& Rath, J. (1992). Six dilemmas in teacher education. Journal of Teacher Education, 43(5), 376-385. doi: 10.1177/0022487192043005007

Ministry of Education, (2002). Strategic plan for early childhood education: Pathways to the future Ngā huarahi arataki. Wellington, New Zealand: Author.

Osgood, J. (2012). Narratives from the nursery: Negotiating professional identities in early childhood. Abingdon, England: Routledge.

Plotz, J. (2001). Romanticism and the vocation of childhood. New York: Palgrave.

Smeyers, P. (2008). Child-rearing: On government intervention and the discourse of experts. Educational Philosophy and Theory, 40(6), 719738.

Stuart, M. (2013). A trinity of saviours - parent, teacher and child: Human Capital Theory and early childhood education in New Zealand. Australasian Journal of Early Childhood, 38(4), 51-57. 


\section{ABOUT THE AUTHOR(S)}

ANDREW GIBBONS

Auckland University of Technology

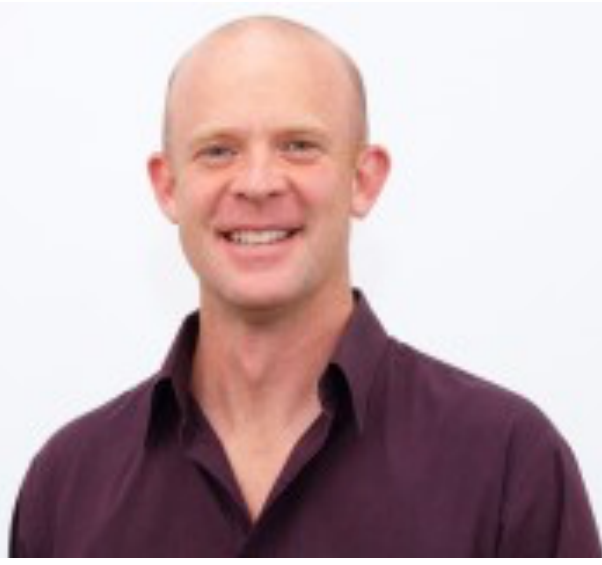

Andrew Gibbons is an early childhood teacher educator and Associate Professor at the School of Education, Auckland University of Technology. He has worked as a journalist, in the social services in England and in ECE in Auckland. Andrew's research draws together a wide range of contexts associated with the work of early childhood teachers and the philosophy of education, with a

particular interest in the role of new media, and the construction of the early childhood teaching profession. He is associate editor of the Encyclopaedia of Educational Philosophy and Theory, and member of the Philosophy of Education Society of Australasia.

Contact: agibbons@aut.ac.nz 